\title{
Financial Performance Appraisal Using Economic Values Added in Emerging Markets: Evidence from Egyptian Listed Firms
}

\author{
Abdel-Karim 0mneya*, Salah Ashraf, Bekheit Bahaa Eldin \\ Department of Finance, College of Management and Technology, Arab Academy for Science and Technology, Alexandria, Egypt \\ Email: *omneya.adel@aast.edu
}

How to cite this paper: Omneya, A.-K., Ashraf, S., \& Eldin, B. B. (2021). Financial Performance Appraisal Using Economic Values Added in Emerging Markets: Evidence from Egyptian Listed Firms. Open Journal of Social Sciences, 9, 415-434. https://doi.org/10.4236/jss.2021.93027

Received: February 17, 2021

Accepted: March 27, 2021

Published: March 30, 2021

Copyright $\odot 2021$ by author(s) and Scientific Research Publishing Inc. This work is licensed under the Creative Commons Attribution International License (CC BY 4.0).

http://creativecommons.org/licenses/by/4.0/

\begin{abstract}
The effectiveness of conventional accounting methods used for firm financial performance measurement and analysis has been criticized. Theorists started to put forward modern financial performance measures although their significance is still under examination by the researchers. Therefore, this study aims to investigate the impact of three contemporary economic based measures; economic value added (EVA), refined economic value added (REVA) and economic value added momentum (EVA Momentum) on firm financial performance in addition to finding out the economic value added based measure with the highest explanatory power relevant to firm financial performance via conducting relative and incremental information content analyses. Data were collected for companies listed in the Egyptian Stock Exchange over the period 2010-2019 excluding the financial sector. Generalized Least Squares (GLS) regression is conducted using the statistical package of EViews-version 10. The results showed significant impact of all the economic value added measures on firm financial performance. In addition, it was found that REVA could be considered as the most effective economic measure in improving and explaining the financial performance.
\end{abstract}

\section{Keywords}

Economic Value Added (EVA), Refined Economic Value Added (REVA), Economic Value Added Momentum (EVA Momentum), Financial Performance Measurement, Return on Assets (ROA), Relative and Incremental Information Content

\section{Introduction}

Finding a superior evaluation tool for firm financial performance is considered 
as one of the most important fundamentals of recent financial researches. However, accounting performance measures such as NP, NOPAT, ROI, EPS, and so on, have been criticized due to their incapability to reflect an organization full cost of capital, thus accounting income cannot be applied in measuring corporate performance and cannot be considered as a consistent interpreter of firm value (He et al., 2020).

Consequently, in order to overcome this drawback through finding a realistic firm financial performance measure, many researchers and consultants made a great effort for revealing a best possible corporate financial performance measurement tool. For that reason, in 1991, Stewart launched the Economic Value Added $\left(\mathrm{EVA}^{\oplus}\right)$ metric as a superior measurement for economic profit and the best driver of shareholder value. Following EVA, Bacidore et al. (1997) proposed refined economic value added (REVA) as a replacement for EVA. Lastly, in 2009, Stewart introduced EVA momentum as the most recent economic value added measurement, registered as a trademark of EVA Dimensions by Stern Stewart advancing earlier EVA work (Mahoney, 2011).

Therefore, this paper is mainly focused on assessing the impact of economic values added on firm financial performance, as to the best of our knowledge, a very few number of previous studies investigated this area of research. This paper is aiming as well to fill the literature gap of assessing REVA and EVA momentum as good economic value based techniques specifically in measuring financial performance. Moreover, a comparative analysis (relative information content) and a hierarchal analysis (incremental information content) will be conducted in order to contribute in determining the economic value added measure that is better able to assess the financial performance. Furthermore, this paper has the purpose of exposing the attention of managers to the most important measures of performance that could be used to analyze and evaluate their firm in a way that assists the management in realizing an improvement in the financial performance.

\section{Literature Review}

\subsection{Financial Performance}

Financial performance is interpreted as the analysis aiming to find out whether the firm succeeded or not in managing its financial resources following the rules by providing a picture of its ability to attain financial goals besides defining how are the conditions of the firm's management to the public (Fahmi, 2014). Even so, in this study financial performance will be represented by an accounting measure, which is the return on assets (ROA). However, according to Nakhaei et al. (2013), ROA is one of the preferred and maybe most widely used measuring technique of firms' financial performance.

\subsection{Economic Value Based Measures}

\subsubsection{Economic Value Added (EVA)}

Stewart (1991) launched the theory of economic value added (EVA) defined as 
"the amount of economic value added by the management to their owners" (Gupta, 2017). Economic value added (EVA) is a measure of a firm financial performance and corresponds to a powerful business tool, which, if implemented correctly, guarantees to improve firm performance and to provide higher returns to shareholders (Salaga et al., 2015). The main idea of EVA is to transform the accounting profit recorded in the financial statements to an economic profit through deducting the cost of capital from it (Weaver, 2001). Yet, economic value added is the difference between net operating profit after tax (NOPAT) and the weighted average cost of capital (WACC).

\subsubsection{Refined Economic Value Added (REVA)}

One of the most important criticisms on EVA is computing the opportunity cost of capital employed using book values ignoring the fact that shareholders usually wait for a return based on the market value. Therefore, in the goal of correcting this flaw, Bacidore et al. (1997), proposed the replacement of EVA by REVA as an advanced measurement criterion for the economic value added involving the residual income after deducting an investor's opportunity cost at the market value not the book value from the NOPAT.

\subsubsection{Economic Value Added Momentum (EVA Momentum)}

EVA Momentum came to light by Stewart in 2009 defined as "the one ratio that tells the whole story". Stewart (2009) illustrated EVA Momentum as the change in economic profit over prior period sales. In contrary to Kaplan and Norton (1992) who declared that there is no single measurement adequate to analyze firm performance; Stewart stated, "EVA Momentum is the single best firm performance measurement tool".

\subsection{Previous Studies}

Empirically, few studies examined the power of economic values added especially with firm financial performance. Some of them showed significance for EVA, REVA and EVA Momentum as economic value based techniques. In 1997, Bacidore et al. examined 600 US firms and he found that the refined economic value added is better than the economic value added in evaluating firms' performance and the value created for its investors. Furthermore, in a study performed by Nikoomaram and Asgari (2009), it was identified that REVA has a higher explanatory power when compared to the conventional and economic based measures. In the same year another study was carried out by Lee and Kim with a study period from 1985 to 2004 and a sample of 353 hospitality firms providing evidence that REVA and MVA are, obviously, valuable firm performance measures.

Moreover, in 2013, Baseri et al. tested 6 hypotheses in Tehran Stock Exchange from 1996 to 2008 identifying a significant relationship between EVA and REVA on one hand and OP on the other hand, in addition to, declaring that EVA and REVA were the main reason behind increasing information content. As well, 
Yan and Wang (2016) in their study carried out on 79 listed electric power firms in china between 2006 and 2013, declared that EVA and REVA are more efficient in analyzing the financial performance of China's electric power enterprises. These results were also supported by Nugroho (2018) when he observed the impact of EVA, MVA, and REVA on stock prices and returns using a sample of 104 manufacturing firms from 2014 to 2016.

Besides, Ceryova et al. (2018) evaluated the business performance of the American multinational technology company Microsoft Corporation using economic value added, economic value added momentum and economic value added margin from 2010 till 2015. They found out that the value of economic value added has notably increased between 2010 and 2015. Recently, Maeenuddina et al. (2020) assessed and presented empirical evidence about the economic value added momentum compared with certain traditional financial measurements with respect to working capital management. The study analyzed a sample of 69 non-financial firms listed in Pakistan Stock exchange for a period consisting of 11 years (20072017). The findings demonstrated that there is a positive significant relationship between working capital management and EVA Momentum.

On the other side, some studies didn't show any significance for EVA, REVA and EVA Momentum as economic value based techniques. As, Nakhaei et al. (2012) argued that according to his study entitled "Performance Appraisal with Accounting and Value Based Measures" which had the purpose to investigate the public firms accepted in Main market of Bursa Malaysia starting from 2001 to 2010, no definite evidence was found supporting that EVA, REVA or even EVA momentum are associated with firms' financial performance. Ultimately, Ashraf (2018) investigated the significance of contemporary measures of firms' financial performance such as REVA and EVA and conventional accountingbased measures for the cement firms of Pakistan starting from 2006 to 2014. The study concluded the irrelevance of ROA, ROE and EPS as evaluation tools of financial performance at the same time as EVA as a modern measurement was proved significant with the long-term firm performance. Last of all, REVA was also proved insignificant and consequently, irrelevant performance measure.

Based on the previous analysis the following hypotheses could be formulated:

H1: There is an impact of economic value-added measures on firm financial performance.

$H_{1 a}$ : There is an impact of $E V A$ on $R O A$.

$H_{1 b}$ : There is an impact of REVA on ROA.

$H_{1 c}$ : There is an impact of EVA Momentum on ROA.

H2: Economic value added ( $E V A$ ) provides superior relative information content compared to other value based measures in explaining the financial performance.

H3: Refined economic value added (REVA) provides superior relative information content compared to other value based measures in explaining the financial performance.

H4: Economic value added Momentum (EVA Momentum) provides su- 
perior relative information content compared to other value based measures in explaining the financial performance.

H5: Economic value added (EVA) provides superior incremental information content compared to other value based measures in explaining the financial performance.

H6: Refined economic value added (REVA) provides superior incremental information content compared to other value based measures in explaining the financial performance.

H7: Economic value added Momentum (EVA Momentum) provides superior incremental information content compared to other value based measures in explaining the financial performance.

\section{Data and Methodology}

\subsection{Variables Description and Calculations}

In this research, the dependent variable is the firm financial performance, the independent variables are the economic value added (EVA), the refined economic value added (REVA) and the economic value added momentum (EVA Momentum). Table 1 shows the research variables and their calculations:

\subsection{Research Model}

In this investigation, a multiple regression model is used, as in the research models presented by Nakhaei et al. (2012), Gupta \& Sikarwar (2016) and Fayed \& Dubey (2016). Thus, the following general equation is created as a statistical research model to analyze the impact of our independent variables on our dependent variable-corporate financial performance (ROA).

$$
\mathrm{ROA}=\beta_{0}+\beta_{1} \mathrm{EVA}+\beta_{2} \mathrm{REVA}+\beta_{3} \mathrm{EVAM}+\varepsilon
$$

Table 1. Variables definition and measurements.

\begin{tabular}{|c|c|c|c|}
\hline Variables & Indicators & Measurement & Reference \\
\hline \multicolumn{4}{|c|}{ Independent variables } \\
\hline \multicolumn{4}{|c|}{ EVA $=$ NOPAT - Capital Charges } \\
\hline $\begin{array}{c}\text { Economic } \\
\text { Value added }\end{array}$ & EVA & $\begin{array}{c}\text { Or } \\
\text { EVA }=\text { NOPAT }-(\text { Invested Capital } \\
\times \text { WACC })\end{array}$ & $\begin{array}{l}\text { Nakhaei et al. (2012) and } \\
\text { Khadafi \& Heikal (2014) }\end{array}$ \\
\hline $\begin{array}{l}\text { Refined Economic } \\
\text { Value Added }\end{array}$ & REVA & $\begin{aligned} \text { REVA }= & \text { NOPT }-(\text { Capital Market } \\
& \text { Value } \times \text { WACC })\end{aligned}$ & $\begin{array}{c}\text { Nakhaei et al. (2012) and } \\
\text { Baseri et al. (2013) }\end{array}$ \\
\hline $\begin{array}{l}\text { Economic Value } \\
\text { Added Momentum }\end{array}$ & $\begin{array}{c}\text { EVA } \\
\text { Momentum }\end{array}$ & $\begin{array}{c}\text { EVA Momentum = } \\
\left(\mathrm{EVA}_{1}-\mathrm{EVA}_{0}\right) / \text { Sales }_{0}\end{array}$ & $\begin{array}{l}\text { Nakaei et al. (2012) and } \\
\text { Fayed and Dubey (2016) }\end{array}$ \\
\hline \multicolumn{4}{|c|}{ Dependent variable } \\
\hline $\begin{array}{l}\text { Corporate Financial } \\
\text { Performance }\end{array}$ & ROA & Net incomel total assets & $\begin{array}{l}\text { Tripathi et al. (2018) and } \\
\text { Maeenuddina et al. } \\
\text { (2020) }\end{array}$ \\
\hline
\end{tabular}


where:

ROA: is return on assets.

EVA: is the economic value added.

REVA: is the refined economic value added.

EVAM: is the economic value added momentum.

$\beta$ : represents the regression coefficient, where $i=0,1,2 \ldots$

$\varepsilon$ : represents the error term.

Precisely, three single regression equations are formed using the Generalized Least Squares (GLS) regression in order to conduct a comparative analysis through testing the relative information content of independent variables. Relative information content (RIC) refers to the information content of one variable measure compared to another using their R-squared values (Erasmus, 2008). More specifically, the $\mathrm{R}$ squared values of three single regression results are analyzed to determine which economic value added technique is supposed to have the highest explanatory power for the financial performance and thus represents a superior relative information content (Gupta and Sikarwar, 2016; Fayed and Dubey, 2016).

Next, to test the incremental information content of EVA, REVA and EVAM, multiple regression equations are employed using GLS regression too. The incremental analysis is based on a hierarchical regression analysis to know the change in R-squared caused by each value-based technique, when added to the model (Erasmus, 2008). Therefore, two equations are conducted for each technique to examine its effect separately. The first equation includes the other two techniques, while the second equation includes the three techniques under study. The R-squared value resulting from each equation is analyzed to determine the incremental change that could be caused by each technique (Gupta and Sikarwar, 2016; Fayed and Dubey, 2016).

The descriptive research model is represented in Figure 1 to describe the impact of economic values added; EVA, REVA and EVA momentum on firm financial performance.
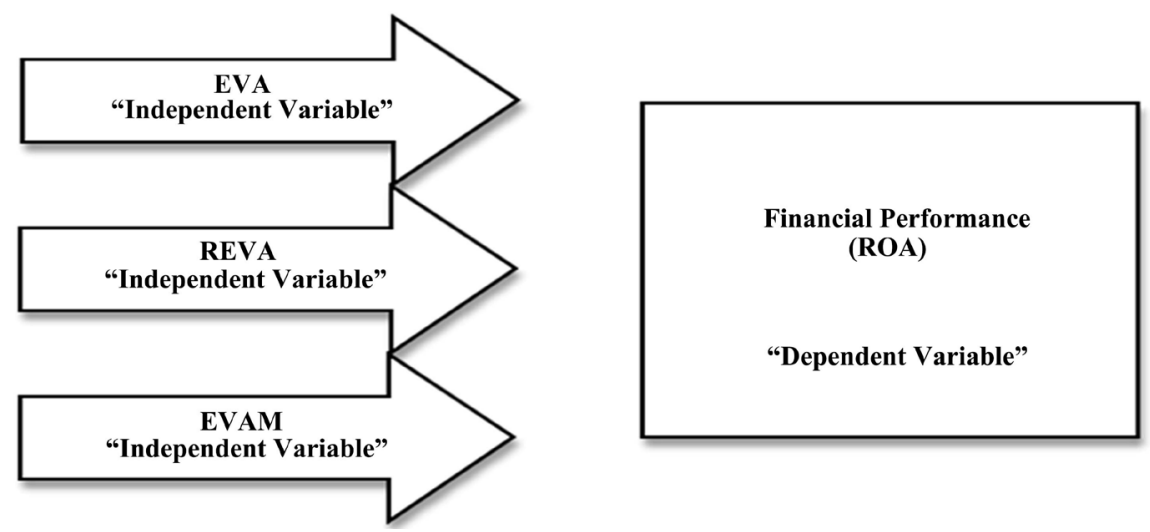

Figure 1. The relationship between independent variables and the dependent variable (descriptive research model). 


\subsection{Sampling and Data Collection}

All data used in this investigation were collected from Osiris database in addition to some financial statements of firms listed in the Egyptian stock exchange that were purchased from the Egyptian Company for Information Dissemination (EGID) in order to complete a balanced panel data set and avoid any survivorship bias. Statistical techniques are conducted using the statistical package of EViews-version 10. The chosen sample is companies listed in the Egyptian Stock Exchange over the period 2010-2019 excluding the financial sector such as banks, leasing and insurance companies since they have to follow different practices (Kangarloei et al., 2012).

After excluding the financial sector companies and according to data availability and accessibility a sample of 196 Egyptian firms is obtained for a period of 10 years, leaving us with 1960 observations. A descriptive analysis is performed as a preliminary step to describe some statistics about the research variables, such as the mean, median, standard deviation, minimum and maximum values. Next, normal distribution is tested for the research variables to be able to decide upon the method of regression analysis to be applied in testing the research hypotheses. It also helps in defining whether to use parametric or non-parametric tests. A fourth step is to test the research hypotheses using the Generalized Least Squares (GLS) regression, where the fixed versus random effects are assessed using Hausman test.

The inferential analysis includes a comparative analysis (relative information content) based on simple regression R-squared value for the impact of each of the economic value-added measures; EVA, REVA and EVA Momentum on the financial performance indicator; ROA. Moreover, a hierarchical analysis (incremental information content) based on multiple regressions is conducted to measure the change representing the added value by each economic technique in correspondence with the financial performance.

\subsection{Measurements}

\subsubsection{Economic Value Added (EVA)}

According to Cordeiro \& Kent (2001), Ismail (2011), Baseri et al. (2013), Nakhaei et al. (2013), Khadafi \& Heikal (2014), Nugroho (2018) and Ahmad et al. (2019), the steps to calculate the economic value added are as follows:

1) Calculating NOPAT (Net Operating After Tax):

$$
\text { NOPAT }=\text { EBIT }(1-\text { Tax Rate })
$$

2) Calculating Invested Capital:

Invested Capital $=$ Total Debt and Equity - short Term Loans without Interest

3) Calculating WACC (Weighted Average Cost of Capital)

$$
\mathrm{WACC}=[(D \times r d)(1-\mathrm{Tax})+(E \times r e)]
$$

\section{Notation}

Capital levels $(D)=($ Total Debt $/$ Total Debt and Equity $) \times 100 \%$ 
Cost of Debt $(\mathrm{rd})=($ Interest Expense $/$ Total Debt $) \times 100 \%$

Level of Capital and Equity $(E)=($ Total Equity/Total Debt and Equity) $\times 100 \%$

Cost of Equity $(r e)=($ NOPAT/Total Equity $) \times 100 \%$

Level of Tax $=($ Tax Expense $\times$ Earnings Before Tax $) \times 100 \%$

4) Calculating Capital Charges

Capital Charges $=$ WACC $\times$ Invested Capital

5) Calculating The Economic Value Added

$$
\mathrm{EVA}=\text { NOPAT }- \text { Capital Charges }
$$

Or

$$
\mathrm{EVA}=\mathrm{NOPAT}-(\mathrm{WACC} \times \text { Invested Capital })
$$

\subsubsection{Refined Economic Value Added (REVA)}

According to Baseri et al. (2013), Nakhaei et al. (2016), Yan \& Wang (2016), Ashraf (2018), Nugroho (2018) and Maeenuddina et al. (2020), REVA is calculated as follows:

$$
\text { REVA }=\text { NOPAT }-(\text { WACC } \times \text { MCapital })
$$

where: NOPAT is net operational profit after tax in period $t$, WACC is weighted average cost of capital, MCAPITAL is the company's market value at the beginning of period $t$.

$$
\begin{aligned}
\mathrm{MV}=\mathrm{MCapital} & =\mathrm{CMVE}+\mathrm{TD}+\mathrm{MI} \\
\mathrm{CMVE} & =\mathrm{CSP} \times \mathrm{TS}
\end{aligned}
$$

where: TD is total debt, CMVE is company market value of equity and MI is minority interest. CSP is company share price, and TS is total share outstanding.

\subsubsection{Economic Value Added Momentum (EVA Momentum)}

According to Mahoney (2011), Fayed \& Dubey (2016), Nakhaei et al. (2016) and Nugroho (2018), EVA momentum is calculated as follows:

$$
\text { EVA Momentum }=\left(\mathrm{EVA}_{1}-\mathrm{EVA}_{0}\right) / \text { Sales }_{0}
$$

where: $\mathrm{EVA}_{1}$ is economic value added in period one, $\mathrm{EVA}_{0}$ is economic value added in the prior period, and Sales $_{0}$ is revenue for the prior period.

\section{Findings and Analysis}

\subsection{Descriptive Statistics}

Table 2 illustrates the descriptive analysis for the research variables using the mean, median, maximum, minimum and standard deviation. The mean value of economic value added EVA is found to be $-14,647$ with a standard deviation of $1,556,943$, a median of -2584.86 along with maximum and minimum values of $54,543,527$ and $-2 \mathrm{E}+07$ respectively. Furthermore, the mean value of refined economic value added REVA is found to be $-106,106$ with a standard deviation of $1,794,125$, a median of -3832.16 in addition to maximum and minimum values of $60,395,300$ and $-2.2 \mathrm{E}+07$ respectively. However, this finding is consistent 
Table 2. Descriptive statistics 2010-2019.

\begin{tabular}{cccccc}
\hline & Mean & Median & Maximum & Minimum & Std. Dev. \\
\hline EVA & -14647 & -2584.86 & $54,543,527$ & $-2 \mathrm{E}+07$ & $1,556,943$ \\
REVA & -106106 & -3832.16 & $60,395,300$ & $-2.2 \mathrm{E}+07$ & $1,794,125$. \\
EVAM & 0.001787 & -0.00057 & 8.817178 & -2.49536 & 0.288919 \\
ROA & 0.036230 & 0.036306 & 0.482838 & -4.79815 & 0.164643 \\
\hline
\end{tabular}

with the findings of Lee and Kim (2009) as well as Ashraf (2018) who reported that REVA with a lower mean value $(-106,106)$ than EVA $(-14,647)$ can be explained by the fact that REVA contains a higher cost of capital due to the use of market value, which is normally greater than the book value used in EVA computation in calculating the cost of capital.

In addition, the mean value of economic value added momentum (EVAM) is found to be 0.001787 with a standard deviation of 0.288919 , a median of -0.00057 along with maximum and minimum values of 8.817178 and -2.49536 respectively. Moreover, the mean value of ROA is found to be 0.036230 with a standard deviation of 0.164643 , a median of 0.036306 , in addition to maximum and minimum values of 0.482838 and -4.79815 respectively. Consistently with Mahoney (2011), Wirawan (2011) and Maeenuddina et al. (2020), EVAM as an economic value added ratio marked a mean value of 0.001787 , which is by default lower than what is marked by ROA as a traditional accounting ratio. However, this is due to the fact that EVAM reflects the economic profit where cost of capital should be deducted while accounting profit such as ROA ignores this.

\subsection{Normality Test}

Table 3 presents the formal testing of normality assumption for the dependent and independent variables via Jarque-Bera test of normality. It could be declared that the research variables are not normally distributed, as long as the corresponding $P$-values are lower than 0.05 . Observing that the formal test identified that the values are not normally distributed, an informal test has to be conducted to determine the approximate normality for a sample of 150 observations or more. Table 3 presents the informal test of normality, where it could be observed that the skewness and kurtosis values are all far away from the accepted level of \pm 1 , which means that the data under study are not approximately normal, Therefore, GLS regression is applied.

\subsection{Testing the Research Hypotheses}

In this section, several steps are followed in order to respond to the research hypotheses, first of all, a comparative analysis is conducted through testing the impact of each independent variable to the extent of the dependent variable in addition to a relative information content analysis based on simple regression to measure the effect of each economic technique; EVA, REVA and EVAM on firm 
Table 3. Normality testing for (2010-2019).

\begin{tabular}{ccccc}
\hline & Skewness & Kurtosis & Jarque-Bera & Probability \\
\hline EVA & 28.03700 & 1053.092 & $67,409,956$ & 0.000000 \\
EVAM & 21.90875 & 666.0954 & $24,675,266$ & 0.000000 \\
REVA & 22.63782 & 831.8290 & $45,675,444$ & 0.000000 \\
ROA & -14.9986 & 414.0849 & $12,996,633$ & 0.000000 \\
\hline
\end{tabular}

financial performance. Then, a hierarchal analysis is done based on multiple regressions to measure the change that could happen in the financial performance due to each of the economic value-added measures under study. Each step mentioned is discussed in a separate subsection below, as follows:

\subsubsection{A Comparative Analysis for the Effect of Economic Value-Added Measures on Firm Financial Performance}

In this subsection, the GLS simple regression technique is used to derive an equation for the impact of each of the economic value-added measures, namely; EVA, REVA and EVAM on the organization's financial performance indicator; ROA. Therefore, three equations are derived in this subsection, which are concerned with responding to the first hypothesis of this research, stated as follows:

H1: There is an impact of economic value-added measures on firm financial performance.

This hypothesis is divided into three sub hypotheses, which are discussed below, each sub hypothesis in a separate equation. Equation (1) is derived for the effect of economic value added (EVA) on return on assets (ROA), as shown in Table 4 using the GLS simple regression equation. Equation (1) responds to the first sub hypothesis of the first hypothesis, which was stated as follows:

\section{$H_{1 a}$ : There is an impact of EVA on ROA.}

It could be observed that there is a significant positive effect of EVA on ROA, as the corresponding $P$-value is $0.0011(P$-value $<0.05)$ and the coefficient is 5.98E-08. Also, R-squared was found to be 0.07 , which means that EVA is able to explain $7 \%$ of the variation in ROA representing its explanatory power relevant to firm financial performance as an economic value added measurement. These findings are consistent with the findings of Ferguson et al. (2005) who observed the effect of implementing economic value added on firm performance explaining that the implementation of economic value added is supposed to enhance the firm's profitability as it contributes in reducing the agency conflict and making better decisions. This argument was also supported by Kosalathevi (2013) assessing the impact of economic value added on financial performance in Sri Lanka for a period of 7 years starting from 2006 to 2012. The results revealed a significant relationship between EVA and financial performance reporting that economic value added could be more accurate than other economic tools when applied for evaluating corporate performance and creating investment strategies. 
Table 4. GLS pooled regression for the effect of EVA on ROA.

\begin{tabular}{ccccc}
\hline Variable & Coefficient & Std. Error & t-Statistic & Prob. \\
\hline C & 0.038503 & 0.002953 & 13.04012 & 0.0000 \\
EVA & $5.98 \mathrm{E}-08$ & $1.83 \mathrm{E}-08$ & 3.266580 & 0.0011 \\
R-squared & 0.072701 & & & \\
Adjusted R-squared & 0.065892 & & & \\
F-statistic & 10.67055 & & & \\
Prob (F-statistic) & 0.001114 & & & \\
\hline
\end{tabular}

The regression equation is estimated as follows:

$$
\mathrm{ROA}=0.038503+5.98-08 * \mathrm{EVA}
$$

Using the fixed versus random effect as shown in Table 5, it could be observed that the $P$-value for the Hausman test is 0.9949 ( $P$-value $>0.05)$, implying that the random effect is the significant effect in the data under study rather than the fixed effect. It could be observed also that there is a significant positive effect of EVA on ROA using the random effect, as the corresponding $P$-value is 0.0012 $(P$-value $<0.05)$. Similarly, there is a significant positive effect of EVA on ROA using the fixed effect, as the corresponding $P$-value is 0.0011 ( $P$-value $<0.05)$.

The above result means that the first sub hypothesis of the first hypothesis is supported, which means that the alternative hypothesis is accepted revealing that there is a significant impact of economic value added (EVA) on return on assets (ROA).

Equation (2) is derived for the effect of refined economic value added (REVA) on return on assets (ROA), as shown in Table 6 using the GLS simple regression equation. Equation (2) responds to the second sub hypothesis of the first hypothesis, which was stated as follows:

\section{$H_{1 b}$ : There is an impact of $R E V A$ on $R O A$.}

It could be observed that there is a significant negative effect of REVA on ROA, as the corresponding $P$-value is $0.000(P$-value $<0.05)$ and the coefficient is $-8.90 \mathrm{E}-09$. Also, R-squared was 0.137 , which means that $13.7 \%$ of the variation in ROA could be explained by REVA representing its explanatory power relevant to firms financial performance as an economic value added measurement. These findings support the findings of Lee and Kim (2009) providing evidence that REVA is a valuable firm performance measure with a high explanatory power. They also reported that REVA with a negative coefficient could be explained by the fact that REVA has a larger cost of capital due to the use of market value in its calculation, which is normally greater than book value used in EVA computation to calculate the cost of capital. These results are also close to the results of Yan and Wang (2016) in China giving evidence that REVA can push managers to take into consideration all the cost of capital (debt and equity) in addition to capital returns to improve the financial performance what will lead in turn to an increase in the wealth of shareholders. 
Table 5. Hausman test for fixed versus random effect of EVA on ROA.

\begin{tabular}{cccccc}
\hline \multirow{2}{*}{ Variable } & \multicolumn{2}{c}{ Fixed Effect } & \multicolumn{2}{c}{ Random Effect } & \multirow{2}{*}{ Hausman Test } \\
\cline { 2 - 5 } & Coefficient & Prob. & Coefficient & Prob. & \\
\hline C & 0.038503 & 0.0000 & 0.039100 & 0.0000 & 0.9949 \\
EVA & $5.98 \mathrm{E}-08$ & 0.0011 & $6.05 \mathrm{E}-08$ & 0.0012 & \\
\hline
\end{tabular}

Table 6. GLS pooled regression for the effect of REVA on ROA.

\begin{tabular}{ccccc}
\hline Variable & Coefficient & Std. Error & t-Statistic & Prob. \\
\hline C & 0.034068 & 0.002938 & 11.59581 & 0.0000 \\
REVA & $-2.55 \mathrm{E}-08$ & $3.25 \mathrm{E}-09$ & -7.850625 & 0.0000 \\
R-squared & 0.137521 & & & \\
Adjusted R-squared & 0.128442 & & & \\
F-statistic & 61.63232 & & & \\
Prob(F-statistic) & 0.000000 & & & \\
\hline
\end{tabular}

The regression equation is estimated as follows:

$$
\mathrm{ROA}=0.034068-2.55 \mathrm{E}-08 * \mathrm{REVA}
$$

Using the fixed versus random effect as shown in Table 7, it could be observed that the $P$-value for the Hausman test is 0.000 ( $P$-value $<0.05)$, implying that the fixed effect is the significant effect in the data under study rather than the random effect. It could be observed also that there is a significant negative effect of REVA on ROA using the fixed effect, as the corresponding $P$-value is 0.0151 ( $P$-value $<0.05)$. On the other hand, there is a significant negative effect of REVA on ROA using the random effect, as the corresponding $P$-value is 0.0002 $(P$-value $<0.05)$.

The above result means that the second sub hypothesis of the first hypothesis is supported, which means that the alternative hypothesis is accepted revealing that there is a significant impact of refined economic value added (REVA) on return on assets (ROA).

Equation (3) is derived for the effect of economic value added momentum (EVAM) on return on assets (ROA), as shown in Table 8 using the GLS simple regression equation. Equation (3) responds to the third sub hypothesis of the first hypothesis, which was stated as follows:

\section{$H_{1 c}$ There is an impact of EVA Momentum on ROA.}

It could be observed that there is a significant positive effect of EVAM on ROA, as the corresponding $P$-value is $0.0025(P$-value $<0.05)$ and the coefficient is 0.055058 . Also, R-squared was 0.068 , which means that $6.8 \%$ of the variation in ROA could be explained by EVAM representing its explanatory power relevant to firms financial performance as an economic value added measurement. Empirically, very few studies investigated the link between EVAM and firm financial performance. However, some of them showed significance for EVAM as 
Table 7. Hausman test for fixed versus random effect of REVA on ROA.

\begin{tabular}{cccccc}
\hline \multirow{2}{*}{ Variable } & \multicolumn{2}{c}{ Fixed Effect } & \multicolumn{2}{c}{ Random Effect } & \multirow{2}{*}{ Hausman Test } \\
\cline { 2 - 5 } & Coefficient & Prob. & Coefficient & Prob. & \\
\hline C & 0.037200 & 0.0000 & 0.036592 & 0.0000 & 0.0000 \\
REVA & $-7.29 \mathrm{E}-09$ & 0.0151 & $-1.08 \mathrm{E}-08$ & 0.0002 & \\
\hline
\end{tabular}

Table 8. GLS pooled regression for the effect of EVAM on ROA.

\begin{tabular}{ccccc}
\hline Variable & Coefficient & Std. Error & t-Statistic & Prob. \\
\hline C & 0.035148 & 0.002891 & 12.15955 & 0.0000 \\
EVAM & 0.055058 & 0.018165 & 3.030949 & 0.0025 \\
R-squared & 0.068242 & & & \\
Adjusted R-squared & 0.060811 & & & \\
F-statistic & 9.186653 & & & \\
Prob(F-statistic) & 0.002485 & & & \\
\hline
\end{tabular}

an economic value added measurement. These findings are close to those of Mahoney (2011) who investigated the US market between 2001 and 2008 supporting the use of EVA momentum as a measure for comparing firms. Furthermore, Ceryova et al. (2018) evaluated the business performance of the American multinational technology company Microsoft Corporation using economic value added momentum and they confirmed that EVAM points out the superior performance highlighting the remarkable productivity of the company. They also stated that EVAM responds to the need to clearly report economic profit as a percentage that can be disaggregated to explore the authentic economic profit drivers whether engendered from productivity profits or rewarding growth or both of them, with each being able to be disaggregated further to show the ultimate primary strengths or weaknesses in the firm at all levels.

The regression equation is estimated as follows:

$$
\mathrm{ROA}=0.035148+0.055058 * \text { EVAM }
$$

Using the fixed versus random effect as shown in Table 9, it could be observed that the $P$-value for the Hausman test is 0.2418 ( $P$-value $>0.05)$, implying that the random effect is the significant effect in the data under study rather than the fixed effect. It could be observed also that there is a significant effect of EVAM on ROA using the fixed effect, as the corresponding $P$-value is 0.0003 ( $P$-value $<$ 0.05). Similarly, there is a significant effect of EVAM on ROA using the random effect, as the corresponding $P$-value is $0.0002(P$-value $<0.05)$.

Therefore, the third sub hypothesis of the first hypothesis is supported, which means that the alternative hypothesis is accepted revealing that there is an impact of economic value added momentum (EVAM) and return on assets (ROA).

In conclusion, based on the previous analysis, the first hypothesis $H 1$ is considered to be fully supported showing an impact of EVA, REVA and EVA momentum on firm financial performance. 
Table 9. Hausman test for fixed versus random effect of EVAM on ROA.

\begin{tabular}{cccccc}
\hline \multirow{2}{*}{ Variable } & \multicolumn{2}{c}{ Fixed Effect } & \multicolumn{2}{c}{ Random Effect } & \multirow{2}{*}{ Hausman Test } \\
\cline { 2 - 5 } & Coefficient & Prob. & Coefficient & Prob. & \\
\hline C & 0.035126 & 0.0000 & 0.037112 & 0.0000 & 0.2418 \\
EVAM & 0.050773 & 0.0003 & 0.051808 & 0.0002 & \\
\hline
\end{tabular}

\subsubsection{Relative Information Content Analysis}

This subsection is aiming to respond to the following hypotheses through conducting RIC analysis:

H2: Economic value added (EVA) provides superior relative information content compared to other value based measures in explaining the financial performance.

H3: Refined Economic value added (REVA) provides superior relative information content compared to other value based measures in explaining the financial performance.

H4: Economic value added momentum (EVA Momentum) provides superior relative information content compared to other value based measures in explaining the financial performance.

After examining the relationships between different economic value-added measures and ROA, it could be observed that the relationship between EVA and ROA was significant positive relationship with an R-squared of 7\%, implying the fact that as EVA increases, ROA will increase also. Moreover, it could be observed that the relationship between EVAM and ROA was significant positive relationship with an R-squared of $6.8 \%$, implying the fact that as EVAM increases, ROA will increase also, while, it could be observed that the relationship between REVA and ROA was significant relationship with an R-squared of 13.7\%. The relationship was found to be negative implying the fact that as REVA increases ROA will decrease.

In conclusion, this means that $H 4$ is supported declaring REVA as the optimum economic technique with the greatest relative information content representing the highest explanatory power of firm financial performance (Nikoomaram and Asgari, 2009).

\subsubsection{An Incremental Analysis for the Effect of Economic Value-Added Measures on Firm Financial Performance}

This sub section is aiming to test the following hypotheses:

H5: Economic value added (EVA) provides superior incremental information content compared to other value based measures in explaining the financial performance.

H6: Refined Economic value added (REVA) provides superior incremental information content compared to other value based measures in explaining the financial performance.

H7: Economic value added momentum (EVA Momentum) provides superior incremental information content compared to other value based meas- 


\section{ures in explaining the financial performance.}

The incremental analysis of the information content of each accounting technique in explaining the financial performance indicator; ROA will be examined. Regarding the first economic technique; EVA, the first equation derived is shown in Table 10, which includes two independent variables; EVAM and REVA. Equation (4) could be stated as follows:

$$
\mathrm{ROA}=0.032587+0.067746 * \mathrm{EVAM}-1.68 \mathrm{E}-08 * \mathrm{REVA}
$$

Also, it could be observed that the R-squared for the equation above is 0.31 , which means that $31 \%$ of the variation in ROA could be explained by EVAM and REVA. In addition, the second equation derived is shown in Table 10, which includes three independent variables; EVA, EVAM and REVA. Equation (5) could be stated as follows:

$\mathrm{ROA}=0.035545+6.94 \mathrm{E}-08^{*} \mathrm{EVA}+0.063164{ }^{*} \mathrm{EVAM}-1.94 \mathrm{E}-08{ }^{*} \mathrm{REVA}$

Also, it could be observed that the R-squared for the equation above is 0.4296 , which means that $42 \%$ of the variation in ROA could be explained by the three economic value-added measures; EVA, EVAM and REVA. This also means that EVA provides incremental information content of $12 \%$ that represents the difference between the R-squared obtained for the two models represented in Table 10.

Regarding the second economic technique; REVA, the first equation derived is shown in Table 11, which includes two independent variables; EVA and EVAM. Equation (6) could be stated as follows:

$$
\mathrm{ROA}=0.037674+5.49 \mathrm{E}-08 * \mathrm{EVA}+0.049779 * \mathrm{EVAM}
$$

Also, it could be observed that the R-squared for the equation above is 0.22 , which means that $21 \%$ of the variation in ROA could be explained by EVA and EVAM. In addition, the second equation derived is shown in Table 11, which includes three independent variables; EVA, EVAM and REVA. Equation (7) could be stated as follows:

$\mathrm{ROA}=0.035545+6.94 \mathrm{E}-08 * \mathrm{EVA}+0.063164 * \mathrm{EVAM}-1.94 \mathrm{E}-08^{*} \mathrm{REVA}(7)$

Also, it could be observed that the R-squared for the equation above is 0.42 , which means that $42 \%$ of the variation in ROA could be explained by the three economic value-added measures; EVA, EVAM and REVA. This also means that

Table 10. Testing the incremental effect of EVA on ROA.

\begin{tabular}{ccccc}
\hline & \multicolumn{2}{c}{ First Equation } & \multicolumn{2}{c}{ Second Equation } \\
\hline Variable & Coefficient & Probability & Coefficient & Probability \\
\hline C & 0.032587 & 0.0000 & 0.035545 & 0.0000 \\
EVA & N/A & N/A & $6.94 \mathrm{E}-08$ & 0.0001 \\
EVAM & 0.067746 & 0.0000 & 0.063164 & 0.0000 \\
REVA & $-1.68 \mathrm{E}-08$ & 0.0002 & $-1.94 \mathrm{E}-08$ & 0.0006 \\
R-squared & & 0.31339 & & 0.42965 \\
\end{tabular}


Table 11. Testing the incremental effect of REVA on ROA.

\begin{tabular}{ccccc}
\hline & \multicolumn{2}{c}{ First Equation } & \multicolumn{2}{c}{ Second Equation } \\
\hline Variable & Coefficient & Probability & Coefficient & Probability \\
\hline C & 0.037674 & 0.0000 & 0.035545 & 0.0000 \\
EVA & $5.49 \mathrm{E}-08$ & 0.0022 & $6.94 \mathrm{E}-08$ & 0.0001 \\
EVAM & 0.049779 & 0.0063 & 0.063164 & 0.0000 \\
REVA & N/A & N/A & $-1.94 \mathrm{E}-08$ & 0.0006 \\
R-squared & & 0.21787 & & \multicolumn{2}{c}{0.42965} \\
\hline
\end{tabular}

REVA provides incremental information content of $21 \%$ that represents the difference between the R-squared obtained for the two models represented in Table 11.

Regarding the third economic technique; EVAM, the first equation derived is shown in Table 12, which includes two independent variables; EVA and REVA. Equation (8) could be stated as follows:

$$
\mathrm{ROA}=0.035435+7.37 \mathrm{E}-08 * \mathrm{EVA}-1.87 \mathrm{E}-08 * \text { REVA }
$$

Also, it could be observed that the R-squared for the equation above is $0.24 \%$, which means that $24 \%$ of the variation in ROA could be explained by EVA and REVA. In addition, the second equation derived is shown in Table 12, which includes three independent variables; EVA, EVAM and REVA. Equation (9) could be stated as follows:

$\mathrm{ROA}=0.035545+6.94 \mathrm{E}-08{ }^{*} \mathrm{EVA}+0.063164 * \mathrm{EVAM}-1.94 \mathrm{E}-08 * \mathrm{REVA}$

Also, it could be observed that the R-squared for the equation above is $0.34 .9 \%$, which means that $35 \%$ of the variation in ROA could be explained by the three economic value-added measures; EVA, EVAM and REVA. This also means that EVAM provides incremental information content of $11 \%$ that represents the difference between the R-squared obtained for the two models represented in Table 12.

According to the information obtained above, it could be claimed that EVA provides incremental information content of $12 \%$ compared to other value based measures in explaining ROA. In addition, EVAM provides incremental information content of $11 \%$ compared to other value based measures in explaining ROA. Moreover, REVA provides incremental information content of $21 \%$ compared to other value based measures in explaining ROA. Therefore, it could be observed that the superior incremental content is provided by REVA.

In conclusion, this result revealed that $\mathrm{H} 6$ is supported declaring REVA as the optimum economic technique with the greatest incremental information content representing the highest explanatory power of firm financial performance $(\mathrm{Ni}$ koomaram and Asgari, 2009).

Table 13 provides a summary of the main results obtained as response to the research hypotheses: 
Table 12. Testing the incremental effect of EVAM on ROA.

\begin{tabular}{ccccc}
\hline & \multicolumn{2}{c}{ First Equation } & \multicolumn{2}{c}{ Second Equation } \\
\hline Variable & Coefficient & Probability & Coefficient & Probability \\
\hline C & 0.035435 & 0.0000 & 0.035545 & 0.0000 \\
EVA & $7.37 \mathrm{E}-08$ & 0.0001 & $6.94 \mathrm{E}-08$ & 0.0001 \\
EVAM & N/A & N/A & 0.063164 & 0.0000 \\
REVA & $-1.87 \mathrm{E}-08$ & 0.0000 & $-1.94 \mathrm{E}-08$ & 0.0006 \\
R-squared & & 0.24480 & & 0.34965 \\
\end{tabular}

Table 13. Summary of research hypotheses results.

\begin{tabular}{|c|c|}
\hline Hypothesis & Result \\
\hline $\begin{array}{l}\text { Hl: There is an impact of economic value-added measures on firm } \\
\text { financial performance. }\end{array}$ & Fully Supported \\
\hline$H_{1 a}:$ There is an impact of $E V A$ on $R O A$. & Supported \\
\hline$H_{1 b}:$ There is an impact of $R E V A$ on $R O A$. & Supported \\
\hline$H_{1 c}:$ There is an impact of EVA Momentum on ROA. & Supported \\
\hline $\begin{array}{l}\text { H2: Economic value added (EVA) provides superior relative } \\
\text { information content compared to other value based measures in } \\
\text { explaining the financial performance. }\end{array}$ & Not Supported \\
\hline $\begin{array}{l}\text { H3: Refined economic value added (REVA) provides superior relative } \\
\text { information content compared to other value based measures in } \\
\text { explaining the financial performance, represented by ROA. }\end{array}$ & Supported \\
\hline $\begin{array}{l}\text { H4: Economic value added momentum (EVA Momentum) provides } \\
\text { superior relative information content compared to other value based } \\
\text { measures in explaining the financial performance. }\end{array}$ & Not Supported \\
\hline $\begin{array}{l}\text { H5: Economic value added (EVA) provides superior incremental } \\
\text { information content compared to other value based measures in } \\
\text { explaining the financial performance. }\end{array}$ & Not Supported \\
\hline $\begin{array}{l}\text { H6: Refined economic value added (REVA) provides superior } \\
\text { incremental information content compared to other value based } \\
\text { measures in explaining the financial performance. }\end{array}$ & Supported \\
\hline $\begin{array}{l}H 7: \text { Economic value added momentum (EVA Momentum) provides } \\
\text { superior incremental information content compared to other value } \\
\text { based measures in explaining the financial performance. }\end{array}$ & Not Supported \\
\hline
\end{tabular}

\section{Conclusion and Recommendations}

This research was planned to carry out a financial performance appraisal for Egyptian listed firms using economic values added. Thus, the impact of three independent variables; economic value added (EVA), refined economic value added (REVA) and economic value added momentum (EVA Momentum) on financial performance was analyzed in our research model using Generalized Least Squares (GLS) regression. As well, a comparative analysis along with a hierarchal analysis was conducted to find out the independent variable with the highest explanatory power. For the purpose of this research, data of firms listed 
in the Egyptian stock exchange were collected for a period of 10 years starting from 2010 to 2019 while excluding the financial sector. Statistical techniques are conducted using the statistical package of EViews-version 10. The results showed significant impact for all the economic values added on firm financial performance. In addition, it was found that REVA could be considered as the most effective economic measure in improving and explaining the financial performance. However, as an end result of the findings of this research a detailed investigation of which components of REVA contribute to information content could be suggested. Besides, it's highly recommended that policy makers and accounting regulators support the evaluation of economic value added by Egyptian companies, especially, through clarifying the change that could occur in financial performance, in light of economic profit. It is also recommended that policy makers seek to improve the level of supervision, and to enhance the standard of reporting in Egypt in order to advance the acceptability of annual reports as the value of contemporary performance measures such as REVA should be considered in the reporting and information requirements along with other evaluation criteria. Moreover, firms have to pay attention to their economic value added especially REVA and give it some worthy consideration and concern. Nevertheless, for the investors, they must be aware of the firm's economic value added and its importance, in order to decide where to invest and supply their funds as they should seek a business applying their needed information content level to guarantee higher level of transparency. Therefore, investors should care about economic profit and give some importance to know complete and accurate information about business performance to enhance their investment decision-making through investing in firms with the economic based measurement tool (REVA). Finally, collecting financial data in Egypt was a hard challenge especially under pandemic. Because of its unavailability, data were collected from two sources; Osiris database in addition to some purchased financial statements to complete the missing data in Osiris, which might produce inconsistency concerning the structure of the financial statements. Therefore, this can be considered as a limitation for our research.

\section{Conflicts of Interest}

The authors declare no conflicts of interest regarding the publication of this paper.

\section{References}

Ahmad, I., Alam, M. S., \& Yameen, M. (2019). A Study of Economic Value Added (EVA) \& Market Value Added (MVA) of Hindustan Petroleum Corporation Limited. Global Journal of Economics and Business, 6, 226-237. https://doi.org/10.31559/GJEB2019.6.1.14

Ashraf, Y. (2018). Is REVA a Better Predictor of Shareholders' Value? A Study of Pakistani Listed Cement Companies. International Journal of Economics, 8, 1-22.

https://doi.org/10.24247/ijecrapr20181 
Bacidore, J. M., Boquist, J. A., Milbourn, T. T., \& Thakor, A. V. (1997). The Search for the Best Financial Performance Measure. Financial Analysts Journal, 53, 11-20. https://doi.org/10.2469/faj.v53.n3.2081

Baseri, M., Atefat, M., \& Baseri, S. (2013). EVA's and REVA's Relative and Growing Information on Benefit Predictions in Tehran Stock Exchange Market Accepted Companies. Proceedings of European Online Journal of Natural and Social Sciences, 2, 401-408.

Ceryova, D., Turcekova, N., Adamickova, I., \& Moravcíkova, D. (2018). Modern Innovative Approaches of Measuring Business Performance. Proceedings of International Conference, 423-430.

Cordeiro, J. J., \& Kent, D. D. (2001). Do EVA(TM) Adopters Outperform Their Industry Peers? Evidence from Security Analayst Earnings Forecasts. American Business Review, 19, 57-63.

Erasmus, P. (2008). Value Based Financial Performance Measures: An Evaluation of Relative and Incremental Information Content. Corporate Ownership \& Control, 6, 66-77. https://doi.org/10.22495/cocv6ilp7

Fahmi, I. (2014). Analisis Kinerja Keuangan. Bandung: Alfabeta.

Fayed, A. M., \& Dubey, S. (2016). An Empirical Study of Impact of EVA Momentum on the Shareholders Value Creation as Compared to Traditional Financial Performance Measures-With Special Reference to the UAE. International Journal of Economics and Finance, 8, 23-38. https://doi.org/10.5539/ijef.v8n5p23

Ferguson, R., Rentzler, J., \& Yu, S. (2005). Does Economic Value Added (EVA) Improve Stock Performance Profitability? Journal of Applied Finance, 4, 101-113.

Gupta, R. (2017). Economic Value Added: Theory and Implications. Journal of Commerce, Economics \& Computer Science (JCECS), 3, 345-350.

Gupta, V. K., \& Sikarwar, E. (2016). Value Creation of EVA and Traditional Accounting Measures: Indian Evidence. International Journal of Productivity and Performance Management, 65, 436-459. https://doi.org/10.1108/IJPPM-01-2014-0008

He, W., Chen, L., \& Liu, W. (2020). Does New Performance Appraisal System (EVA) Affect Earnings Management? Nankai Business Review International, 11, 191-216. https://doi.org/10.1108/NBRI-10-2019-0051

Ismail, I. (2011). The Ability of EVA (Economic Value Added) Attributes in Predicting Company Performance. African Journal of Business Management, 5, 4993-5000.

Kangarloei, S. J., Motavassel, M., Arzanlu, E., \& Soleimani, B. (2012). The Investigation of the Relationship between Economic Value Added (EVA) and Return on Assets (ROA) in Tehran Stock Exchange (TSE). Business Management Dynamics, 1, 1-5.

Kaplan, R. S., \& Norton, D. P. (1992). The Balanced Scorecard-Measures that Drive Performance. Harvard Business Review, 70, 71-91.

Khadafi, M., \& Heikal, M. (2014). Financial Performance Analysis Using Economic Value Added in Consumption Industry in Indonesia Stock Exchange. American International Journal of Social Science, 3, 219-226.

Kosalathevi, T. (2013). Impact of Economic Value Added on Market Value Added: Special Reference to Selected Private Banks in Sri Lanka. Developing Country Studies, 3, 102-107.

Lee, S., \& Kim, W. G. (2009). EVA, Refined EVA, MVA, or Traditional Performance Measures for the Hospitality Industry? International Journal of Hospitality Management, 28, 439-445. https://doi.org/10.1016/j.ijhm.2009.01.004

Maeenuddina, R. B., Hussain, A., Hafeez, M., Khan, M., \& Wahi, N. (2020). Economic Value Added Momentum \& Traditional Profitability Measures (ROA, ROE \& ROCE): 
A Comparative Study. Test Engineering and Management, 83, 3762-13774.

Mahoney, R. (2011). EVA Momentum as a Performance Measure in the United States Lodging Industry. Ames, IA: Iowa State University.

Nakhaei, H., Hamid, N. I. N., Anuar, M. A., \& Nakhaei, K. (2016). Is Refined Economic Value Added More Associated with Stock Return than Accounting Measures? The Malaysian Evidence. Society and Economy in Central and Eastern Europe, 38, 69-85. https://doi.org/10.1556/204.2016.38.1.5

Nakhaei, H., Hamid, N. I. N., Anuar, M. B., \& Nakhaei, K. (2012). Performance Evaluation Using Accounting Variables (Net Profit and Operational Profit) and Economic Measures. International Journal of e-Education, e-Business, e-Management and e-Learning, 2, 443-448. https://doi.org/10.7763/IJEEEE.2012.V2.161

Nakhaei, H., Nik Intan, H., Melati, A., \& Nakhaei, K. (2013). Evaluation of Company Performance with Accounting and Economic Criteria in Bursa Malaysia. Journal of Global Business and Economics, 6, 49-63.

Nikoomaram, H., \& Asgari, M. R. (2009). Proposing a Model for Predicting Tehran Stock Exchange Output Using REVA, EVA, EP and EPS Metrics.

Nugroho, M. (2018). The Effect of Economic Value Added (EVA), Market Value Added (MVA), Refined Economic Value Added (REVA) on Stock Prices and Returns Stock at Manufacturing Industries Who Listed on Indonesia Stock Exchange (BEI). Archives of Business Research, 6, 173-188. https://doi.org/10.14738/abr.612.5843

Salaga, J., Bartosova, V., \& Kicova, E. (2015). Economic Value Added as a Measurement Tool of Financial Performance. Procedia Economics and Finance, 26, 484-489. https://doi.org/10.1016/S2212-5671(15)00877-1

Stewart, G. B. (1991). The Quest for Value: A Guide for Senior Managers. New York: HarperBusiness.

Stewart, G. B. (2009). EVA Momentum: The One Ratio That Tells the Whole Story. Journal of Applied Corporate Finance, 21, 74-86. https://doi.org/10.1111/j.1745-6622.2009.00228.x

Tripathi, M., Kashiramka, S., \& Jain, P. K. (2018). Flexibility in Measuring Corporate Financial Performance, EVA versus Conventional Earnings Measures: Evidences from India and China. Global Journal of Flexible Systems Management, 19, 123-138. https://doi.org/10.1007/s40171-017-0178-0

Weaver, S. C. (2001). Measuring Economic Value Added: A Survey of the Practices of EVA Proponents. Journal of Applied Finance, 11, 50-61.

Wirawan, D. I. (2011). Effects of EVA (Economic Value Added), EVA Spread, EVA Momentum and Return on Assets on Stock Return. PH.D. Thesis, Yogyakarta: Universitas Gadjah Mada.

Yan, Q., \& Wang, Y. (2016). REVA-Based Value Analysis on Listed Companies of Power Industry. In Proceedings of International Conference on Modeling, Simulation and Optimization Technologies and Applications (pp. 377-379). Paris: Atlantis Press. https://doi.org/10.2991/msota-16.2016.82 